\title{
LEGITYMACJA PROCESOWA \\ W SPRAWACH 0 ZAPRZESTANIE TZW. NIEEKOLOGICZNEJ REKLAMY W ŚWIETLE PRZEPISÓW USTAWY - PRAWO OCHRONY ŚRODOWISKA
}

\section{ACTING IN THE CAPACITY OF PLAINTIFF AND DEFENDANT IN CASES OF SO-CALLED NON-ECOLOGICAL PUBLICITY CESSATION IN LIGHT OF THE PROVISIONS OF THE ACT - ENVIRONMENTAL PROTECTION LAW}

\section{STRESZCZENIE}

Ustawa z dnia 27 kwietnia 2001 roku - Prawo ochrony środowiska, wprowadzając zakaz tzw. nieekologicznej reklamy, przewiduje

* Dr nauk prawnych, Zakład Postępowania Cywilnego WPiA UAM. 
jako środek jego egzekwowania powództwo cywilne i równocześnie wyposaża w uprawnienie do jego wytoczenia organizację ekologiczną. Treść przepisów ustawy nie rozstrzyga jednak kwestii, czy organizacja ekologiczna jest jedynym podmiotem uprawnionym do wszczynania postępowania sądowego w tej sprawie, czy też nie jest wyłączone występowanie z powództwem o zaprzestanie reklamy również przez inne podmioty, w tym w szczególności prokuratora. Za słuszne należy przyjąć drugie z wyrażonych stanowisk. Skoro ustawodawca poddał sprawy o zaprzestanie reklamy zawierającej w treści lub w formie elementy sprzeczne $\mathrm{z}$ ustawą pod rozpoznanie i rozstrzygnięcie sądu cywilnego, to uczynił je sprawami cywilnymi w znaczeniu przyjętym $\mathrm{w}$ art. 1 k.p.c. Zgodnie zaś z ogólnymi zasadami prokurator może wszczynać postępowania w każdej sprawie, przewidziane zaś w przepisach szczególnych wyłączenia nie obejmują spraw o zaprzestanie reklamy zakazanej w ustawie - Prawo ochrony środowiska. Odnośnie zaś do legitymacji biernej, to w świetle obowiązujących przepisów należy opowiedzieć się za przyznaniem jej podmiotowi emitującemu reklamę. Pozwoli to wyeliminować sytuacje, w których prawomocny wyrok zakazujący reklamy o treści lub formie sprzecznych z przepisami w rzeczywistości nie zostanie wykonany na skutek objęcia egzekucją wyłącznie producenta wówczas, gdy nie będzie miał on realnego wpływu na zachowania pozostającego poza postępowaniem egzekucyjnym emitenta.

\section{Słowa kluczowe}

Legitymacja procesowa, nieekologiczna reklama, organizacja ekologiczna, sprawa cywilna.

\section{ABSTRACT}

The Act of 27 April 2001 - Environmental Protection Law by forbidding so-called non-ecological publicity provides for civil action to enforce the execution of the law, and at the same time equips an environmental organization with the right to institute the civil suit. The content of the Act, however, does not settle the question whether the environmental organization is the only entity authorized to initiate proceedings in this case, or if other entities are not excluded from the initiation to stop publicity, including, in particular, the prosecutor. There are reasons to adopt the other of the expressed positions. Since 
the legislature has put the matter to cease publicity which contains in content or in form the elements in conflict with the law to be heard and determined by civil courts, it has made them civil cases in the meaning of statute 1 of the civil law code. According to the general principle, the prosecutor may institute proceedings in any case; and specific provisions provided for in exemptions do not include cases of cessation of publicity prohibited by law - Environmental Protection Law. As for the passive capacity, in light of existing rules one should opt for granting it to the entity issuing the advertisement. This will allow to eliminate situations in which a final judgment prohibiting publicity in content or in form that is contrary to the provisions will in fact not be executed due to the execution of the law on the manufacturer only, while it has no real impact on the actions of the issuer remaining outside enforcement proceedings.

\section{Keywords}

Acting in the capacity of plaintiff and defendant, non-ecological publicity, an environmental organization, civil suit.

\section{WPROWADZENIE}

Ustawodawca, wprowadzając w przepisie art. 80 ustawy Prawo ochrony środowiska ${ }^{1}$ zakaz reklamy lub innego rodzaju promocji towaru lub usługi, polegających na propagowaniu modelu konsumpcji sprzecznego z zasadami ochrony środowiska i zrównoważonego rozwoju, w szczególności przez wykorzystywanie obrazu dzikiej przyrody do promowania produktów i usług negatywnie wpływających na środowisko przyrodnicze, przewiduje równocześnie środek prawny służący eliminowaniu tego rodzaju negatywnie ocenionej działalności. Co znamienne, środkiem tym czyni cywilne powództwo, a do wytoczenia go uprawnia mocą wyraźnego przepisu organizację ekologiczną. Mimo to z postępowaniem sądowym w sprawie o zaprzestanie

1 Ustawa z dnia 27 kwietnia 2001 roku, Dz.U. z 2008 r. Nr 25, poz. 150 ze zm. 
reklamy o treści lub formie sprzecznej z ustawą wiąże się szereg problemów, w tym dotyczących kwestii, kto w istocie jest legitymowany do występowania $\mathrm{w}$ tym postępowaniu w charakterze czynnej i biernej strony procesowej. Celem niniejszego opracowania jest wyjaśnienie wątpliwości związanych z podstawowym dla analizowanego, jak i każdego postępowania sądowego zagadnieniem, jakim jest jego podmiotowy zakres.

\section{LEGITYMACJA CZYNNA}

Przewidując w przepisie art. 328 ustawy, iż z roszczeniem o zaprzestanie reklamy lub innego rodzaju promocji towaru lub usługi, jeśli są one sprzeczne z art. 80 ustawy, mogą występować organizacje ekologiczne, ustawodawca wyraźnie przyznał legitymację procesową czynną konkretnie wskazanemu w ustawie podmiotowi. Mimo to wątpliwość wywołuje kwestia, czy z brzmienia przepisu: organizacje ekologiczne mogą występować do sądu z roszczeniem o zaprzestanie reklamy lub innego rodzaju promocji towaru lub usługi, jeśli reklama ta lub inny rodzaj promocji sprzeczne są z art. 80 wynika, iż legitymacja ta przysługuje „wyłącznie organizacji ekologicznej” czy też „także organizacji ekologicznej". O tym, że sygnalizowana tu kwestia okazuje się rzeczywiście sporna, świadczy fakt, iż w literaturze zostały wyrażone poglądy opowiadające się zarówno za pierw- 
szym $^{2}$, jak i za drugim możliwym rozwiązaniem ${ }^{3}$. Przy tym uzasadnieniem dla tego drugiego stanowiska miała być wywiedziona na podstawie nieobowiązujących już przepisów kodeksu postępowania cywilnego ${ }^{4}$ o postępowaniu odrębnym w sprawach gospodarczych teza, że legitymację czynną w sprawach przeciwko przedsiębiorcy ma każdy podmiot, co wynikać miało z przepisu art. $479^{1} \S 2$ pkt 2 k.p.c. W konsekwencji przyjmowano, że przepisy ustawy Prawo ochrony środowiska dodatkowo przyznają tę legitymację organizacjom ekologicznym. Istotnie, językowa wykładnia cytowanego przepisu art. 80 ustawy nie pozwala na jednoznaczne rozstrzygnięcie powstałego problemu. Bezsprzecznie, z punktu widzenia celu, jaki ma on realizować, a tym samym zapewnienia jak najszerszej możliwości urzeczywistnienia tego celu korzystne byłoby przyznanie uprawnienia do wszczynania postępowań w sprawie zaprzestania nieekologicznej reklamy każdemu podmiotowi. Z drugiej strony wydaje się dość mało prawdopodobne, by inne podmioty prywatne korzystały z owej legitymacji, co sprawiłoby, że w praktyce ewentualna legitymacja czynna każdego podmiotu miałaby charakter fasadowy. W każdym razie odpowiedzi na pytanie o zakres legitymacji czynnej w rozważanym przypadku należałoby poszukiwać z uwzględnieniem przepisów prawa materialnego, w tym w sposób szczególny funkcji przepisu art. 328 ustawy oraz okoliczności, czy służy on ochronie interesu prywatnego, czy też może interesu publicznego. Przyznanie uprawnienia do wystę-

2 Stanowisko, że organizacje ekologiczne są jedynym podmiotem upoważnionym do wystąpienia, zajął K. Gruszecki, Prawo ochrony środowiska. Komentarz, Warszawa 2011, s. 634-635; zob. także M. Mazur, Formy zbiorowe ochrony prawa osobistego do środowiska, „Państwo i Prawo” 2006, nr 5, s. 104 w przypisie 9, gdzie co prawda nie wskazuje się na wyłączność legitymacji organizacji ekologicznej, ale zauważa się jej kluczową rolę w zakresie ochrony środowiska w ogólności.

3 B. Rakoczy, Pojęcie sprawy gospodarczej z zakresu ochrony środowiska, „Przegląd Sądowy” 2003, nr 4, s. 89 uznał zaś, że zgodnie z art. $479^{1} \S 2$ pkt 2 kpc legitymację czynną w sprawach przeciwko przedsiębiorcy ma każdy podmiot, a art. 80 ustawy Prawo ochrony środowiska dodatkowo przyznaje tę legitymację organizacjom ekologicznym.

4 Ustawa z dnia 17 listopada 1964 roku, Dz.U. Nr 43, poz. 296 ze zm. 
powania z żądaniem o udzielenie ochrony prawnej wszystkim podmiotom wymagałoby, po pierwsze, uznania, że ochrona ta jest wymagana ze względu na jakieś dobro wspólne, interes publiczny, po drugie zaś, oznaczałoby przyjęcie, iż istnieją podstawy dla wprowadzenia w tym zakresie actio popularis.

Bezsprzecznie powództwo przewidziane $\mathrm{w}$ przepisie art. 328 ustawy jest środkiem ochrony prawnej środowiska. Powstaje jednak pytanie, czy dochodzona z jego użyciem ochrona jest realizowana $\mathrm{w}$ interesie prywatnym czy też publicznym, to jest dla dobra jednostki czy dla dobra wspólnego. O ochronie środowiska naturalnego jako dobra wspólnego stanowi wprost przepis art. 323 ust. 2 ustawy, przyznając roszczenie o przywrócenie stanu zgodnego $\mathrm{z}$ prawem i podjęcie wskazanych środków zapobiegawczych Skarbowi Państwa, jednostce samorządu terytorialnego i organizacji ekologicznej. Na tle tego przepisu wyjaśniono pojęcie „dobra wspólnego" w ochronie środowiska jako sytuację, w której zagrożone jest dobro ogółu, a nie dobro jednostki, na skutek naruszenia środowiska lub jego zagrożenia, które charakteryzuje się szerszym oddziaływaniem lub możliwością oddziaływania niż tylko w sposób zagrażający prawom jednostki ${ }^{5}$, nadto nie da się zindywidualizować podmiotu, któremu została wyrządzona szkoda lub któremu szkoda bezpośrednio zagraża ${ }^{6}$. Podejmowana w takich okolicznościach ochrona jest ochroną w interesie publicznym, a nie prywatnym. Nie wydaje się przy tym, by istniały jakiekolwiek przeszkody do przyjmowania takiego rozumienia pojęcia środowiska jako dobra wspólnego w sposób generalny, a więc także na użytek innych przepisów z zakresu ochrony środowiska. Co prawda przepis art. 328 ustawy nie wskazuje, tak jak to czyni wspomniany przepis art. 323 ust. 2 ustawy, na skutek posługiwania się reklamą bądź innym środkiem promocji w postaci zagrożenia dla środowiska naturalnego jako dobra wspólnego, niemniej

5 J. Ciechanowicz-McLean, Z. Bukowski, B. Rakoczy, Prawo ochrony środowiska. Komentarz, Warszawa 2008, s. 515.

2/2013 2002, s. 106 . 
sens przepisu art. 80 ustawy zdaje się przemawiać właśnie za tym rozwiązaniem. Znaczenie zakazu reklamy spełniającej cechy wskazane w ustawie Prawo ochrony środowiska sprowadza się bowiem - najogólniej mówiąc - do zapobiegania kształtowania się w świadomości społecznej zgody na taki styl życia, którego skutki mogą oddziaływać niekorzystnie na środowisko. W brzmieniu przepisu art. 80 ustawy trudno doszukać się treści mogących przemawiać bezpośrednio za jego ochronną rolą także w zakresie prywatnych interesów jednostek. Nie oznacza to oczywiście, by nie istniały jakiekolwiek podstawy do dochodzenia ochrony owych indywidualnych interesów w związku z emisją reklamy zawierającej treści opisane w przepisie art. 80. Nie można wszak wykluczyć sytuacji, w której jednostka, powołując się na naruszenie jej poczucia estetyki poprzez wizerunek bądź treść reklamy umieszczonej na sąsiedniej nieruchomości wystąpi z roszczeniem na podstawie przepisu art. 144 kc. Trzeba jednak zauważyć, że uprawnienie do dochodzenia roszczenia o zaniechanie immisji (w tym przypadku pośredniej niematerialnej) przysługiwałoby także wówczas, gdyby ustawa Prawo ochrony środowiska nie zawierała przepisu art. 80. Również konstrukcja przepisu art. 328 ustawy pozwala wywieść wniosek, iż zawiera on środek procesowy służący ochronie środowiska jako dobra wspólnego. Brak jest, jak było powiedziane, w jego treści wyraźnego wskazania, iż przewidziany w nim środek służyć ma dochodzeniu ochrony $\mathrm{w}$ interesie publicznym, nie ma też przeciwstawienia sytuacji przewidującej dochodzenie roszczeń ze względu na interes publiczny realizacji roszczeń w interesie prywatnym, jak to jest w dwóch kolejnych paragrafach przepisu art. 323 ustawy. Ta druga okoliczność również może świadczyć o tym, iż ustawodawca, konstruując powództwo o zaprzestanie reklamy, nie znajdował miejsca jego zastosowania do realizacji interesów jednostek. Istotniejsze jest jednak to, że prawodawca, wyposażając organizację ekologiczną w legitymację procesową czynną, równocześnie upoważnił ją do działania w procesie nie tylko we własnym imieniu, ale i na swoją rzecz. Czyni to ową organizację niejako rzecznikiem interesu publicznego w zakresie ochrony środowiska poprzez zakaz nieekologicznej 
reklamy. Przecież we wszystkich tych przypadkach, w których ustawodawca uprawnia do występowania w charakterze strony procesowej inne podmioty aniżeli te, których interes prywatny jest przedmiotem postępowania i którego praw lub obowiązków postępowanie dotyczy, daje temu wyraz przez wskazanie, iż wytaczają one powództwo na rzecz innych osób. Jest tak chociażby w przypadkach wskazanych w przepisach art. $61,63^{1,} 63^{3} \mathrm{kpc}$, gdzie wyraźnie zaznacza się, że wskazane w przepisach organizacje pozarządowe, inspektor pracy czy rzecznik konsumentów wytaczają powództwa na rzecz obywateli. We wszystkich tych sytuacjach legitymacja czynna wskazanych podmiotów ma charakter uzupełniający w stosunku do legitymacji samych zainteresowanych. Przepis art. 328 ustawy nie zawiera takiego wskazania, co czyni analogiczną sytuację uregulowaną w tym przepisie do sytuacji prokuratora wytaczającego powództwo na podstawie przepisu art. 57 kpc czy do sytuacji, w której, na gruncie niejednokrotnie przywoływanego przepisu art. 323 ust. 2 ustawy z powództwem o przywrócenie stanu zgodnego z prawem i zaniechanie naruszeń występuje Skarb Państwa, jednostka samorządu terytorialnego czy właśnie organizacja ekologiczna. Ostatecznie należy stwierdzić, że powództwo o zaprzestanie reklamy nieekologicznej jest środkiem ochrony środowiska jako dobra wspólnego, a podmiotem wyposażonym w uprawnienie do jego wytaczania jest organizacja ekologiczna, działająca $\mathrm{w}$ interesie publicznym. Natomiast przepis art. 328 ustawy nie stanowi źródła uprawnień do wszczynania postępowania przez inne podmioty, w szczególności nie przyznaje takiego uprawnienia każdej jednostce.

Należy jeszcze rozważyć, czy stwierdzenie, iż legitymacja czynna przysługuje w omawianej sprawie organizacjom ekologicznym, a nie przysługuje zaś jednostkom, oznacza, że faktycznie nie można jej przyznać żadnemu innemu podmiotowi. Chodzi mianowicie o legitymację prokuratora, który na mocy art. 7 kpc może żądać wszczęcia postępowania w każdej sprawie, jak również wziąć udział w każdym toczącym się postępowaniu, jeżeli według jego oceny wymaga tego ochrona praworządności, 2/2013 praw obywateli lub interesu społecznego. Jak wiadomo, wszę- 
dzie tam, gdzie ustawodawca uznał udział prokuratora za nieuzasadniony, dokonał stosownych wyłączeń w przepisach, co dotyczy jednak wyłącznie spraw niemajątkowych z zakresu prawa rodzinnego, konkretnie zaś spraw o rozwód i separację. Nie wydaje się więc, by przyznanie legitymacji do wszczynania postępowania $\mathrm{w}$ przedmiocie zaprzestania reklamy nieekologicznej organizacji ekologicznej mocą przepisów ustawy o ochronie środowiska było równoznaczne z uchyleniem ogólnych reguł zawartych w przepisach kodeksu postępowania cywilnego, a tym samym z pozbawieniem analogicznego uprawnienia prokuratora. Oczywiście, w takich przypadkach prokurator nie będzie działać w procesie na rzecz oznaczonych podmiotów, a więc nie będzie realizować niczyich interesów prywatnych. Jego ewentualny udział w procesie opierać się przy tym będzie na przesłance ochrony interesu społecznego lub praworządności. Wszak posługiwanie się reklamą o treści wskazanej w przepisie art. 80 ustawy stanowi naruszenie ustawowego zakazu, jest zatem działaniem niezgodnym z prawem.

\section{LEGITYMACJA BIERNA}

Zdecydowanie więcej wątpliwości zdaje się wywoływać zagadnienie, przeciwko komu powództwo o zaprzestanie reklamy winno być wytoczone. Przepis art. 328 ustawy bezpośrednio wskazuje jedynie podmiot legitymowany czynnie. Brak jest natomiast wyraźnych wskazówek interpretacyjnych co do oznaczenia podmiotu, przeciwko któremu powództwo winno być skierowane. Trzeba zwrócić uwagę na okoliczność, że kwestii, przeciwko komu należy wytoczyć powództwo przewidziane w przepisie art. 328 ustawy nie można rozpatrywać w oderwaniu od przepisu art. 80, tego mianowicie, który wskazuje, jakich treści reklama nie powinna zawierać. W pierwszej kolejności należy zatem zastanowić się, do kogo adresowany jest tenże przepis art. 80. Stanowi on, iż reklama lub inny rodzaj promocji towaru lub usługi nie powinny zawierać treści propa- 
gujących model konsumpcji sprzeczny z zasadami ochrony środowiska i zrównoważonego rozwoju, a w szczególności wykorzystywać obrazu dzikiej przyrody do promowania produktów i usług negatywnie wpływających na środowisko przyrodnicze. Brzmienie tego przepisu odnosi się więc do reklamy bądź promocji w znaczeniu przedmiotowym, jako do pewnego określonego produktu, nie zaś do czynności z nią związanych i zawiera zakaz wykorzystywania w reklamie lub promocji ściśle określonych treści oraz formy. Wydaje się więc, iż jakkolwiek treść tego przepisu nie jest przydatna dla jednoznacznego oznaczenia podmiotu biernie legitymowanego w ewentualnym postępowaniu sądowym, to jednak pozwala, z uwzględnieniem zasad doświadczenia życiowego i praktyki rynkowej, ustalić krąg podmiotów, do których zawarty w nim zakaz jest skierowany. Potencjalnymi adresatami tego zakazu mogą być trzy kategorie podmiotów: 1) podmiot, na którego rzecz reklama jest tworzona i wprowadzana na rynek albo organizowana jest promocja, gdyż jako producent lub sprzedawca pewnych towarów i usług liczy na wzrost zysków dzięki reklamie lub promocji (dla uproszczenia nazywany będzie dalej „producentem”), 2) podmiot, który tworzy ową reklamę („projektant”), 3) podmiot, który emituje reklamę albo organizuje promocję („podmiot emitujący"). W przypadku pierwszej grupy podmiotów wynikający z przepisu art. 80 ustawy zakaz musiałby oznaczać rezygnację z posługiwania się reklamą albo promocją swoich towarów lub usług, sprzeczną z zasadami opisanymi w tym przepisie. W stosunku do drugiej grupy zakaz oznaczałby niezamieszczanie z własnej inicjatywy albo odmowę zamieszczania w tworzonej reklamie elementów (treści lub obrazów) wskazanych $\mathrm{w}$ przepisie jako potencjalnie niekorzystne z punktu widzenia środowiska przyrodniczego. Wreszcie dla trzeciej grupy pod- 
miotów treść przepisu art. 80 ustawy oznaczałaby odmowę emitowania tego rodzaju reklam lub organizowania promocji. $\mathrm{Na}$ marginesie warto wskazać, że z przepisu art. 80 ustawy można wywieść dalsze jeszcze konsekwencje o pewnym znaczeniu dla rozważanej kwestii. Po pierwsze, jego treść wyraźnie sugeruje, iż podmioty, do których zakaz nieekologicznej reklamy jest skierowany, to podmioty prowadzące działalność gospodarczą, skoro przedmiotem owej reklamy lub promocji mają być towary lub usługi ${ }^{7}$. Po drugie zaś, przyjęcie, że treść przepisu art. 80 zawiera w istocie zakaz nieekologicznej reklamy lub promocji musi konsekwentnie oznaczać, że wszelkie umowy, których przedmiotem jest taka reklama lub promocja są jako sprzeczne z ustawą nieważne na mocy przepisu art. 58 kc Wracając natomiast na grunt rozważań nad legitymacją bierną $\mathrm{w}$ procesie o - zgodnie $\mathrm{z}$ terminologią przyjętą przez ustawodawcę - zaprzestanie reklamy lub promocji, należy zbadać, czy $\mathrm{w}$ istocie każdy z podmiotów wskazanych powyżej jako adresaci zakazu wypływającego z przepisu art. 80 ustawy powinien występować $\mathrm{w}$ ewentualnym postępowaniu sądowym $\mathrm{w}$ charakterze strony pozwanej. Tutaj istotne wydają się dwie kwestie: możliwa do wywiedzenia z przepisów treść dochodzonego roszczenia oraz funkcja, jaką spełniać ma przepis art. 80, zwłaszcza zaś moment, od którego zakaz nieekologicznej reklamy staje się aktualny z punktu widzenia także racjonalności. Jak słusznie podkreśla się w literaturze, reklama lub promocja naruszają przepis art. 80 dopiero wtedy, gdy mają możliwość dotarcia do odbiorcy, a więc od momentu jej rozpowszechnienia, sama zaś reklama lub promocja, nawet zawierająca treści wskazane w tym przepisie nie jest jeszcze równoznaczna z propagowaniem modelu konsumpcji sprzecznego $\mathrm{z}$ zasadami

7 Na fakt, że zawarty w przepisie art. 80 ustawy - Prawo ochrony środowiska zakaz tzw. reklamy nieekologicznej dotyczy w istocie reklamy gospodarczej, a nie na przykład społecznej czy politycznej, zwrócono już zresztą uwagę w literaturze, por. D. Dziedzic-Chojnacka, D. Chojnacki, Zakaz reklamy nieekologicznej w polskim prawie ochrony środowiska, „Radca Prawny” 2007, nr 4, s. 57. 
ochrony środowiska i zrównoważonego rozwoju ${ }^{8}$. Jest to uwaga słuszna w kontekście ratio owego przepisu, to znaczy eliminowaniu elementów mogących zachęcać do - najogólniej mówiąc - zachowań nieekologicznych, w konsekwencji, rzecz jasna, stwarzać potencjalne zagrożenia dla środowiska. Dlatego istotny jest tu element uzewnętrznienia owej reklamy lub promocji, to znaczy skierowania jej do odbiorców: dopóki bowiem reklama lub promocja nie zostanie upubliczniona przez wprowadzenie jej do obrotu w jakikolwiek sposób, którego skutkiem jest możliwość zapoznania się z nią przez podmioty inne aniżeli uczestniczące $\mathrm{w}$ jej powstaniu i skierowaniu do emisji, nie wywołuje żadnych konsekwencji, w tym niepożądanych w świetle przepisu art. 80. Natomiast co do treści roszczenia przewidzianego $\mathrm{w}$ przepisie art. 328, to pobieżna analiza prowadzi do wniosku, że użyte przez ustawodawcę sformułowanie „zaprzestanie” dotyczy fazy, w której reklama jest już wprowadzona na rynek (a zatem potencjalnie może wywoływać opisane w przepisie art. 80 negatywne dla środowiska skutki), a zarazem odnosi się do czynności będącej w toku (trwającej, niezakończonej). Takie rozumienie, narzucające się na podstawie lektury przepisu wraz ze wspomnianym wcześniej wymaganiem uzewnętrznienia zdaje się eliminować z kręgu osób, przeciwko którym roszczenie to przysługuje, twórcę reklamy bądź promocji. Nie wydaje się bowiem racjonalne żądanie „zaprzestania” reklamy lub promocji, która już istnieje jako gotowy produkt, tak jak nieuzasadnione jest żądanie „zaprzestania" reklamy lub promocji na etapie jej tworzenia, gdyż wówczas nie jest znany jeszcze jej kształt (forma, treść) ostateczny. Nie można zatem przesądzać z całą pewnością, że efekt istotnie będzie naruszał przepis art. 80. Natomiast żadna z obu wskazanych wyżej okoliczności nie pozwala wyeliminować z kręgu podmiotów potencjalnie biernie legitymowanych ani podmiotu emitującego reklamę czy organizującego promocję, ani producenta (sprzedawcy), na rzecz którego reklama lub

8 J. Ciechanowicz-McLean, Z. Bukowski, B. Rakoczy, Prawo ochrony środowiska..., s. 192. 
promocja są prowadzone. W literaturze jako strona pozwana $\mathrm{w}$ procesie o zaprzestanie reklamy wskazywany jest albo wyłącznie podmiot, który emituje reklamę lub organizuje promocję ${ }^{9}$, albo producent towarów lub usług mających być przedmiotem reklamy, jak i ten, kto zajmuje się jej upublicznieniem ${ }^{10}$. Przyznanie legitymacji biernej wyłącznie przedsiębiorcy zajmującemu się emisją reklamy bądź organizacją promocji na zasadach sprzecznych z przepisem art. 80 ustawy uzasadnia się przy tym z jednej strony faktem, że to właśnie jego działalność stanowi bezpośrednie oddziaływanie na odbiorców ${ }^{11}$, z drugiej zaś okolicznością, iż roszczenie o zaprzestanie reklamy stanowi ograniczenie wolności gospodarczej, stąd wykładnia przepisu będącego źródłem tego roszczenia winna być ścisła, a nawet ścieśniająca ${ }^{12}$. Natomiast wyposażenie $\mathrm{w}$ tę legitymację obydwóch wskazanych podmiotów upatruje się w konieczności „zindywidualizowania podejścia w zależności od sprawy stanowiącej przedmiot rozstrzygania", co stanowić ma konsekwencję praktycznej możliwości publikowania reklamy w różnych mediach i związanej z tym - w razie przyjęcia koncepcji wyposażenia $\mathrm{w}$ legitymację bierną jedynie emitenta reklamy - nieracjonalnej konieczności wytaczania osobnych powództw w stosunku do każdego z mediów z osobna ${ }^{13}$. Podkreśla się także, że przyznanie legitymacji do występowania w charakterze pozwanego tylko podmiotowi emitującemu reklamę oznaczałoby, że wydanie przez sąd wyroku zakazującego emisji reklamy jednemu podmiotowi nie powodowałoby, że także inne podmioty (np. inne stacje telewizyjne) nie mogłyby jej emitować ${ }^{14}$.

9 B. Rakoczy, Pojęcie..., s. 89; J. Ciechanowicz-McLean, Z. Bukowski, B. Rakoczy, Prawo ochrony środowiska..., s. 522.

10 K. Gruszecki, Prawo ochrony środowiska..., s. 634-635; M. Górski, M. Pchałek, W. Radecki, J. Jerzmański, M. Bar, S. Urban, J. Jendrośka, Prawo ochrony środowiska. Komentarz, Warszawa 2011, s. 1122.

11 B. Rakoczy, Pojęcie..., s. 89.

12 J. Ciechanowicz-McLean, Z. Bukowski, B. Rakoczy, Prawo ochrony środowiska..., s. 523.

13 K. Gruszecki, Prawo ochrony środowiska..., s. 635.

14 M. Górski, M. Pchałek, W. Radecki i.in., Prawo ochrony środowiska..., s. 1122 . 
Wydaje się, że rozwiązania problemu należy ciągle poszukiwać poprzez odkodowanie użytego w przepisie art. 328 zwrotu „zaprzestanie reklamy" jako przedmiotu przyznanego organizacji ekologicznej roszczenia, $\mathrm{z}$ równoczesnym uwzględnieniem celu, jaki ustawodawca przypisał regulacji zawartej w przepisie art. 80. Celem tym zaś jest wyeliminowanie sytuacji, w której na rynku funkcjonowałaby reklama lub inny rodzaj promocji o treściach wskazanych w przepisie jako niepożądane, gdyż mogą one ostatecznie spowodować postawy społeczne sprzeczne z zasadami ochrony środowiska i zrównoważonego rozwoju, zagrażające środowisku. Jak niejednokrotnie wskazywano, ustawodawca posługując się w przepisie art. 328 ustawy w sposób świadomy bądź nie - sformułowaniem „zaprzestanie reklamy", nie precyzuje, jakie konkretnie czynności winny być zaniechane, a tym samym, jakiej działalności pozostającej w związku z reklamą towarów lub usług dotyczy żądanie zaniechania. Tym samym wykładnia językowa tego przepisu nie jest pomocna w rozwiązaniu tego zagadnienia. W każdym jednak razie użyte w przepisie pojęcie „zaprzestanie reklamy” jest szerokie i nie wydaje się, by uzasadnione było ograniczanie czy wręcz utożsamianie go z wyrażeniem „zaprzestanie emitowania reklamy". Biorąc pod uwagę ratio legis przepisu art. 80, nie wydaje się pozbawione sensu tłumaczenie zwrotu „zaprzestanie reklamy” jako „zaniechanie wprowadzania jej do obrotu, to znaczy emitowania, upubliczniania, jak i zaniechania posługiwania się taką reklamą". Należy wszak zwrócić uwagę na okoliczność, iż podmiot emitujący reklamę (np. media) nie czyni tego z własnej inicjatywy, lecz na zlecenie (na podstawie czynności prawnej) innego podmiotu, tego mianowicie, który jest producentem lub sprzedawcą towarów lub usług będących przedmiotem reklamy i który w konsekwencji liczy na to, że wyemitowana reklama przyczyni się do zwiększenia przez niego zysków. Zatem bez czynnego udziału tego drugiego podmiotu nie mogłoby dojść do emisji reklamy naruszającej zakaz przewidziany w ustawie (chyba że emitent reklamy sam byłby jego producentem lub sprzedawcą). Jest to o tyle istotne, że wspomniany cel przepisu art. 80 nie zostanie w pełni osiągnię- 
ty przez zakazanie wyrokiem sądu emitowania reklamy podmiotowi, który w ten sposób naruszył ustawowy zakaz. Cel ten zostanie natomiast osiągnięty dopiero wówczas, gdy sąd w wyroku zobowiąże do zaprzestania reklamowania lub promowania w sposób naruszający przepis art. 80 towarów lub usług ich producenta lub sprzedawcę, ten bowiem podmiot jest w gruncie rzeczy pierwotną „siłą sprawczą” sytuacji, w której doszło do naruszenia przepisu art. 80. Jak zresztą zauważono w doktrynie, objęcie wyrokiem tylko pozwanego emitenta reklamy wydaje się jedynie działaniem prowizorycznym, gdyż nie uniemożliwi producentowi reklamowania towarów lub usług poprzez emisję reklamy przez inne podmioty. Wydaje się więc, że główną przyczyną powstania sytuacji, w której naruszony jest zakaz przewidziany w przepisie art. 80, jest działanie producenta (sprzedawcy) towarów lub usług, polegające na zleceniu podmiotowi zajmującemu się emisją reklam lub organizowaniem promocji, wprowadzenie reklamy bądź innego rodzaju promocji na rynek. $\mathrm{Z}$ tego punktu widzenia istotnie nie przekonuje stanowisko opowiadające się za przyznaniem legitymacji biernej wyłącznie emitentowi reklamy. Z kolei zakazanie przez sąd posługiwania się reklamą bądź promocją naruszającą ustawowy zakaz producentowi (sprzedawcy) towarów lub usług będzie musiało oznaczać odstąpienie od korzystania z reklam aktualnie funkcjonujących na rynku (już wyemitowanych), ale także niewykorzystywanie dla promowania będących przedmiotem zakazanej reklamy towarów lub usług tej reklamy w przyszłości. Bez znaczenia z punktu widzenia celu przepisu art. 80 winno być, jakimi sposobami pozwany producent (sprzedawca) doprowadzi do realizacji obowiązku zawartego w wyroku (oczywiście, z uwagi na nieważność z mocy prawa umowy o emisję reklamy lub zorganizowanie promocji $\mathrm{z}$ powodu sprzeczności z ustawą nie będzie wchodzić tu w grę wypowiedzenie tej umowy). Podobnie bez znaczenia winna pozostawać kwestia ewentualnych rozliczeń między stronami.

Przyjęcie stanowiska, iż dopuszczalne jest przyznanie w procesie o zaprzestanie reklamy nieekologicznej legitymacji biernej zarówno emitentowi reklamy, jak i producentowi 
reklamowanych towarów lub usług wywołuje konieczność rozważenia ich ewentualnych wzajemnych relacji w procesie, w szczególności zaś ustalenia charakteru przysługującej im ewentualnie legitymacji procesowej. Jako punkt wyjścia dla tej analizy posłużą następujące niekwestionowane twierdzenia. Po pierwsze, podstawą roszczenia przeciwko każdemu z pozwanych jest naruszenie zakazu wynikającego z ustawy, po drugie, działania każdego z podmiotów naruszające ten zakaz są działaniami o innej treści oraz, po trzecie, z uwagi na nieważność umowy o świadczenie usług w przedmiocie emisji reklamy lub zorganizowania innego rodzaju promocji podmioty te nie są powiązane $\mathrm{w}$ zakresie dochodzonego przeciwko nim roszczenia żadnym węzłem prawnym. Należy zaznaczyć, że na gruncie prawa materialnego brak jest przepisu, który bezpośrednio odnosiłby się do analogicznej sytuacji, to znaczy przepisu regulującego wzajemne relacje materialnoprawne kilku podmiotów, których zachowanie stanowiłoby naruszenie ustawowego zakazu. Przepis art. $441 \S 1$ kc stanowi, że jeżeli kilka osób ponosi odpowiedzialność za szkodę wyrządzoną czynem niedozwolonym, ich odpowiedzialność jest solidarna. Jednak przepis ten reguluje wprost kwestię odpowiedzialności deliktowej, której przesłanką, zresztą wyrażoną bezpośrednio w jego treści, jest fakt wyrządzenia szkody. Naruszenie przepisu art. 80 ustawy Prawo ochrony środowiska nie polega w założeniu ustawodawcy na wyrządzeniu szkody. Przepis ten ma bowiem charakter prewencyjny ${ }^{15}$. Nie wydaje się zatem zasadne, by przenosić w tym przypadku zasady odpowiedzialności deliktowej, nawet odpowiednio, na sytuacje objęte odpowiedzialnością prewencyjną. Zakładając, że problem wzajemnych relacji materialnoprawnych pomiędzy producentem i emitentem reklamy dałoby się, jak się wydaje, rozwiązać, posługując się konstrukcją solidarności niewłaściwej, należałoby jeszcze ustalić ich ewentualne powiązania na płaszczyźnie procesowej. W orzecznictwie przyjęto, że wskazanie jednego roszczenia, którego uprawnio-

15 Podobnie J. Pakuła, Glosa do wyroku s. apel. Z dnia 12 stycznia 2010 roku, VI ACa 666/09, „Przegląd Prawa Ochrony Środowiska” 2011, nr 2, s. 129 oraz B. Rakoczy, Pojęcie..., s. 88. 
ny może dochodzić od dwu lub więcej osób na różnych podstawach, stwarza podstawę do współuczestnictwa materialnego (ale ani nie do jednolitego, ani nie do koniecznego) ${ }^{16}$. Stanowisko o istnieniu współuczestnictwa materialnego w przypadku solidarności niewłaściwej zostało zaprezentowane także w doktrynie: tam, gdzie występuje różna odpowiedzialność, nieuwarunkowana istnieniem jakiegoś stosunku prawnego łączącego zobowiązane podmioty, a świadczenie jest jedno, do spełnienia którego każdy z nich jest zobowiązany, przedmiot sporu jest jeden, a każdy ze współuczestników jest z nim powiązany ${ }^{17}$. Istotne jest tu więc przede wszystkim, czy ciążący na podmiotach zobowiązanych obowiązek jest dla nich wspólny, to znaczy, czy jest jeden, a zadośćuczynienie mu przez jednego jest wystarczające dla stwierdzenia jego wygaśnięcia. Jeżeli przyjmie się, że zakaz wyrażony w przepisie art. 80 ustawy można utożsamić z obowiązkiem powstrzymywania się od reklamy nieekologicznej poprzez niezlecanie jej emitowania i poprzez jej nieemitowanie, to w kontekście prowadzonych rozważań zagadnienie to winno przybrać postać pytania, czy powstrzymanie się przez producenta od zlecenia emisji takiej reklamy emitującemu spowoduje wykonanie obowiązku wynikającego z ustawy, oraz czy powstrzymanie się przez emitującego od emisji takiej reklamy na zlecenie producenta przyniesie również taki skutek. Rzecz jasna, chodzi tu o konkretną reklamę zleconą do rozpowszechnienia konkretnemu emitentowi. Odpowiedź na postawione pytania zdaje się, że jest twierdząca: bez zlecenia emisji reklamy nie byłoby naruszenia zakazu $\mathrm{z}$ art. 80 ustawy przez jej rozpowszechnienie, natomiast niewyemitowanie jej nie mogłoby skutkować naruszeniem zakazu także przez producenta. Jakkolwiek rozważana kwestia wymagałaby głębszej analizy z punktu widzenia prawa materialnego, z pewną ostrożnością można by zaryzykować stwierdzenie, że w omawianej sytuacji zachodzi współuczestnictwo materialne

16 Uchwała SN z dnia 6 września 1991 roku, III CZP 77/91, OSNC 1992, z. 5 , poz. 68 .

17 Zob. M. Jędrzejewska, Wspótuczestnictwo procesowe. Istota - zakres rodzaje, Warszawa 1975, s. 83. 
oparte na wspólności obowiązku przy ewentualnie częściowej tylko tożsamości podstawy faktycznej. Znacznie więcej trudności rodzi potwierdzenie postawionej w orzecznictwie i doktrynie tezy, że w przypadku relacji materialnoprawnych opartych na konstrukcji solidarności niewłaściwej owo współuczestnictwo nie ma charakteru ani współuczestnictwa koniecznego, ani jednolitego. Zarówno pierwszy, jak i drugi z wymienionych rodzajów współuczestnictwa materialnego ma wynikać $\mathrm{z}$ istoty spornego stosunku prawnego albo z przepisu ustawy. Ponieważ brak jakiegokolwiek przepisu, który wskazywałby wprost na konieczny lub jednolity charakter współuczestnictwa w omawianym przypadku, jedynym źródłem tych rodzajów współuczestnictwa mogłaby być więc istota spornego stosunku prawnego. W doktrynie podkreśla się, że współuczestnictwo konieczne oparte na istocie spornego stosunku prawnego występuje wówczas, gdy więź między współuczestnikami jest tak silna, że powoduje konieczność jednolitego i równoczesnego rozstrzygnięcia wobec nich wszystkich, przy jednoczesnym braku przepisu uprawniającego poszczególne podmioty do samodzielnego działania, chyba że podmioty uprawnione do samodzielnego działania mogłyby działać wyłącznie w imieniu wszystkich, a więc $\mathrm{w}$ charakterze przedstawicieli podmiotów pozostających poza procesem ${ }^{18}$. W konsekwencji współuczestnictwo konieczne nie zachodzi, jeżeli przy silnej więzi wewnętrznej pomiędzy podmiotami istnieje przepis dający poszczególnym podmiotom prawo do samodzielnego działania oraz jeżeli nie istnieje nierozerwalna więź oparta na istocie stosunku prawnego i nie istnieje przepis wskazujący na konieczność łącznego występowania w procesie tych podmiotów (jak np. w przypadku zobowiązań solidarnych) ${ }^{19}$. Żadnej z wymienionych sytuacji nie da się stwierdzić $\mathrm{w}$ omawianym przypadku. Trzeba więc przyjąć, że brak tu współuczestnictwa koniecznego. W konsekwencji powód mógłby pozwać jednym pozwem

18 M. Jędrzejewska, Wspótuczestnictwo..., s. 148.

19 M. Jędrzejewska, K. Weitz w: T. Ereciński (red.), Kodeks postępowania cywilnego. Komentarz. Postępowanie rozpoznawcze, t. 1, Warszawa 2012, s. 387. 
obydwa podmioty zobowiązane do powstrzymywania się od nieekologicznej reklamy, ale mógłby też poprzestać na wytoczeniu powództwa przeciwko jednemu z nich. Dla rozstrzygnięcia omawianego problemu pomocny może okazać się argument natury praktycznej, a mianowicie kwestia efektywności wyroku zobowiązującego do zaprzestania reklamy. Jak wiadomo, obowiązek będący przedmiotem dochodzonego, a następnie egzekwowanego roszczenia, z racji niepieniężnej natury, podlegać będzie egzekucji na podstawie przepisu art. 1051 kpc, polegającej - w uproszczeniu - na wymuszeniu zaprzestania czynności poprzez nałożenie na dłużnika egzekwowanego grzywny. W przypadku skierowania egzekucji do emitującego reklamę sprawa wydaje się jasna. Natomiast skierowanie egzekucji do producenta może faktycznie nie doprowadzić do wykonania wyroku. W tej bowiem sytuacji to na producenta, nie zaś na emitenta reklamy zostanie nałożona grzywna, a zatem możliwa jest sytuacja, w której producent podporządkuje się treści wyroku (dobrowolnie bądź pod wpływem czynności egzekucyjnych), natomiast reklama będzie mimo to w obiegu, gdyż dłużnik może nie mieć realnego wpływu na zachowanie emitenta, który - nie będąc podmiotem postępowania egzekucyjnego, a wcześniej także i pozwanym w postępowaniu rozpoznawczym - może nadal rozpowszechniać reklamę. Powyższy problem nie wystąpi, rzecz jasna, w przypadku opowiedzenia się za koncepcją, według której legitymacja bierna w procesie o zaprzestanie nieekologicznej reklamy zostanie przyznana wyłącznie emitentowi.

\section{PODSUMOWANIE}

Przeprowadzona analiza przemawia za potraktowaniem przepisu art. 328 ustawy - Prawo ochrony środowiska jako uzupełniającego regulacje ogólne wynikające z unormowań zawartych w kodeksie postępowania cywilnego. Sprowadza się do przyjęcia - przy uwzględnieniu specyfiki i kontekstu spraw o zaprzestanie nieekologicznej reklamy - iż organizacja ekologiczna 
nie jest jedynym podmiotem uprawnionym do występowania $\mathrm{w}$ charakterze powoda $\mathrm{w}$ tego rodzaju sprawach. Jakkolwiek zakres owej czynnej legitymacji jest znacznie ograniczony, to brakuje podstaw, w szczególności przepisów szczególnych pozbawiających tej legitymacji prokuratora, który jest uprawniony do wszczynania postępowań w każdej sprawie cywilnej, poza wyraźnie wyłączonymi mocą ustaw.

Argumenty wywiedzione $\mathrm{z}$ obowiązujących przepisów, ale także wzgląd na aspekty pragmatyki i racjonalności zdają się przemawiać za przyznaniem legitymacji biernej podmiotowi emitującemu reklamę. Z jednej strony pozwoli to ominąć sygnalizowane trudności z zakwalifikowaniem ewentualnego współuczestnictwa po stronie pozwanej, z drugiej zaś wyeliminuje nieracjonalne sytuacje, w których prawomocny wyrok zakazujący reklamy o treści lub formie sprzecznych z przepisami w rzeczywistości nie zostanie wykonany na skutek objęcia egzekucją wyłącznie producenta przy braku jego wpływu na pozostającego poza postępowaniem egzekucyjnym emitenta. Trudno bowiem opowiadać się za konstrukcją, która - mimo że być może poprawna w świetle obowiązujących przepisów, a nawet pożądana - nie doprowadzi do oczekiwanych skutków. Trzeba zgodzić się z poglądem, że wyposażenie w legitymację procesową bierną wyłącznie emitenta reklamy spowoduje potencjalną mnogość równoczesnych czy następujących po sobie procesów z udziałem podmiotów reprezentujących różne, niezależne od siebie media, w których reklama została zamieszczona. Jednak na podstawie treści przepisów nie jest możliwe odtworzenie narzędzia, które pozwalałoby na skuteczne i jednoczesne wymuszenie respektowania zakazu wyrażonego w przepisie art. 80 ustawy. W szczególności za narzędzie takie nie może być uznana ewentualna możliwość pozwania jednym pozwem zarówno producenta, jak i emitującego reklamę. Zakładany skutek myłby zostać osiągnięty w zasadzie w przypadku przypisania obydwóm podmiotom legitymacji procesowej łącznej, a występującemu wówczas pomiędzy nimi współuczestnictwu procesowemu jednolitego charakteru. Z uwagi na fakt, że uczynienie tego na podstawie tego kryterium, jakim jest istota stosunku 2/2013 prawnego jest problematyczne, a w każdym razie wymagające 
głębszych, oddzielnych studiów, wydaje się, że najlepszym rozwiązaniem byłoby wprowadzenie przez ustawodawcę przepisu, zgodnie z którym producent i emitent winni być pozwani łącznie, a wyrok zapadły w sprawie $\mathrm{z}$ ich udziałem miałby - zgodnie $\mathrm{z}$ terminologią przyjętą w przepisie art. $73 \S 2 \mathrm{kpc}-$ dotyczyć wszystkich współuczestników.

\section{BIBLIOGRAFIA}

Ciechanowicz-McLean J., Bukowski Z., Rakoczy B., Prawo ochrony środowiska. Komentarz, Warszawa 2008.

Dziedzic-Chojnacka D., Chojnacki D., Zakaz reklamy nieekologicznej w polskim prawie ochrony środowiska, „Radca Prawny” 2007, nr 4.

Ereciński T. (red.), Kodeks postępowania cywilnego. Komentarz. Postępowanie rozpoznawcze, t. 1, Warszawa 2012.

Górski, Pchałek M., Radecki W., Jerzmański J., Bar M., Urban S., Jendrośka J., Prawo ochrony środowiska. Komentarz, Warszawa 2011.

Gruszecki K., Prawo ochrony środowiska. Komentarz, Warszawa 2011.

Jędrzejewska M., Wspótuczestnictwo procesowe. Istota - zakres - rodzaje, Warszawa 1975.

Mazur M., Formy zbiorowe ochrony prawa osobistego do środowiska, „Państwo i Prawo” 2006, nr 5.

Pakuła J., Glosa do wyroku s. apel. Z dnia 12 stycznia 2010 roku, VI ACa 666/09, „Przegląd Prawa Ochrony Środowiska” 2011, nr 2.

Radecki W., Odpowiedzialność prawna w ochronie środowiska, Warszawa 2002.

Rakoczy B., Pojęcie sprawy gospodarczej z zakresu ochrony środowiska gospodarczej, „Przegląd Sądowy” 2003, nr 4.

Kontakt - e-mail:

mucha@amu.edu.pl 